\title{
The Royal Academy Exhibition
}

$\mathrm{I}^{\mathrm{T}}$ is always of interest to the student of natural science to see the impression which the objects of his study produce upon the artistic eye. In respect of the range of nature study at the Royal Academy there is, however, a lamentable falling off in the matter of natural history. With the exception of Mr. Peter Scott's "Barnacle Geese in April" (210) there is scarcely anything of note, and the almost total absence of studies of big game, notably of the great carnivora, is very disappointing. Yet the material is not lacking, for there is a remarkably fine exhibition of contemporary big game pictures in a neighbouring gallery, not "mere transcripts of the objects of Natural History" but true artistic compositions.

Landscape, however, continues to be well represented. There is a large number of pleasing pictures of English scenes in which architecture provides the focal feature amidst natural surroundings. In the verdant landscape of the English plain a village church or a distant cathedral provides the artist with the massive and formal element which is lacking in a country from which the harder rocks are absent. Again, in the hilly landscapes we find studies such as that by Mr. Stanley Royle of "Mont Orgueil Castle, Jersey" (265), in which an architectural feature crowning an eminence develops the rocky forms to a pitch of steepness and a regularity of symmetry towards which Nature seems to strive but never quite attains. Such examples of artistic treatment provide a valuable lesson for the scientific observer, for the artistic outlook is more in accordance with the natural faculties of the eye than that which results from classifying objects by their physical qualities.

Among the most pleasing illustrations of the combination of architectural and natural features are those of bridges, with massive piers and arches spanning smoothly flowing water. In "A Welsh Bridge" (189) by Mr. Oliver Hall, the combination is enhanced by a rocky background which harmonises with the massive masonry. This picture brings home very forcibly the need for scheduling such structures as ancient monuments for preservation, a lesson emphasised by Mr. Charles Cundall's beautiful picture of a sad event, "The Demolition of Waterloo Bridge" (447).

In the illustration of the seasons, the Academy will greatly miss the late Mr. J. Farquharson's snow studies, of which, however, the present exhibition contains one small example, "In Glen Garry" (558).

In natural scenery the mode of illumination is scarcely less important than the features themselves, and we are indebted to Mr. J. Olsson for his beautiful study of moonlight_-"Moonlit Surf : Irish Coast" (297). There is also one very fine study made in the deepening darkness of the night, "Santa Maria della Salute, Venice" (532), the diploma work of Mr. Richard Sickert.

Mr. A. E. Kelly's "Mount Sefton, New Zealand" (669) is one of the few pictures of the scenery of distant lands. The want of studies of tropical scenery will be particularly felt by those who can recall the magnificent sunset effects in the equatorial belt.

Among the portraits are several of personal interest to the scientific community. Mr. Francis Dodd's "The Lord Rutherford of Nelson, O.M." (1207) is a strong drawing of a strong face. Mrs. Dodgson's drawing of the late Prof. H. H. Turner (1253) renders admirably the quiet humour of the eyes beneath a thoughtful brow. Mr. Augustus John has portraits of Lord Conway of Allington (284) and Prof. J. C. McLennan (288). Mr. George Harcourt gives us a portrait of Colonel R. E. B. Crompton (368) which reveals a vigorous personality, and in Sir James Crichton-Browne by Mr. Oswald Birley (314) we see a fine rendering of calm and thoughtful reminiscence.

VAUGHAN CORNISH.

\section{The Royal Jubilee}

\section{Addresses from the Royal Societies of London and Edinburgh}

$\mathrm{I}^{\mathrm{N}}$ addition to the messages of devotion and loyalty sent to the King from civic and governing authorities of the Empire at home and overseas, expressing congratulations to His Majesty upon the celebration of the silver jubilee of his accession, addresses were presented by a number of representative scientific societies. The addresses submitted by the Royal Societies of London and Edinburgh are reprinted below.

To the King's Most Excellent Majesty

May it please Your Majesty,

We, Your loyal and dutiful subjects, the President, Council and Fellows of the Royal Society, humbly 
beg leave to offer Your Majesty, the beloved patron of our Society, our respectful congratulations upon the completion of the twenty-fifth year of Your Majesty's reign.

The Royal Society of London since its foundation by King Charles the Second, has continued, under the illustrious patronage of each of Your Majesty's predecessors, to devote itself to the Promotion of Natural Knowledge, for which it was founded. During Your Majesty's reign, the advance of Science has exercised an ever increasing influence on human thought, and, in its practical applications, on the material conditions of man's life and activities. The Royal Society is proud to think that, with Your Majesty's continued patronage and approval, it has remained the centre for the recognition and promo. tion of the work of Your Majesty's subjects for the Advancement of Science throughout Your great Empire.

The Royal Society accordingly claims the proud privilege of being permitted to offer this loyal tribute of esteem to YourMajesty, on behalf of men of Science, not only in the Mother Country, but also throughout the Empire. It is offered in the earnest hope that Your Majesty, with Her Most Gracious Majesty the Queen, may long continue to reign over Your devoted and loyal subjects.

On behalf of the Council and Fellows of the Royal Society.

\section{To the King's Most Excellent MaJesty}

May it please Your Majesty,

We of the Royal Society of Edinburgh bring to Your Majesty and to Her Most Gracious Majesty the Queen our humble and hearty congratulations on the happy issue of the five-and-twenty years during which Your Majesty has ruled over a loyal and devoted people.

These years of Your Majesty's reign mark a great epoch in History. War has shaken the world and changed the lives and thoughts and circumstances of men. But the devotion of the people to Your Majesty's Throne and Person has deepened and strengthened through all the changes and tumults of the age.

In this Royal Society the Natural and Physical Sciences are our daily occupation and task. Never have these Sciences flourished more than under Your Majesty's protection nor have they ever been more diligently applied to the service and advantage of mankind. Now for the first time in all the world men go their daily journeys above the clouds: all nations and languages send speech and music through the air : and Your Majesty's voice is grown familiar in Your people's ears even to the ends of the earth throughout Your world-wide Empire and Dominions.

And that Your Majesty may long be spared in health and wealth to live and reign this Society will Ever Pray.

\section{Obituary}

Sir John Rose Bradford, Bart., K.C.M.g., c.B., C.B.E., F.R.S.

$\mathrm{T}$ HE death of Sir John Rose Bradford, on April 7, after some months of increasing disability, will be deeply regretted in many scientific circles. Born in London on May 7, 1863, as the son of Abraham Rose Bradford, a naval surgeon, he was educated at University College School, University College, and University College Hospital, London, and had a brilliant career as a student, published physiological papers before he became qualified medically, and was specially interested in biology. His papers, however, were mainly physiological, and covered a wide field : on the electrical phenomena associated with secretion; on the innervation of the blood vessels ; and particularly on the renal function, which he later extended to the subject of uræmia and disease. He probably hesitated about his life's work, whether strictly scientific work or medicine, for he was elected George Henry Lewes student in physiology in 1888, his predecessors being C. S. Roy (1879), L. C. Wooldridge (1882), and C. S. Sherrington (1884), and his immediate successors G. N. Stewart and E. H. Hankin jointly (1889). The decision was made when he accepted accelerated appointment as assistant physician to University College Hospital. His physiological researches gained him the fellowship in 1894 of the Royal Society, of which he was later secretary (1908-15). He thus, like his teacher,
Sydney Ringer, combined the attitude of an allround biologist with that of a practising physician.

At the Royal College of Physicians of London, Sir John was elected a fellow in 1897, gave the Goulstonian lectures on the pathology of the kidneys (1904), the Croonian lectures on Bright's disease and its varieties (1920), the Lumleian lectures on the clinical experience of a physioian during the campaign in France and Flanders in 1914-19, and the Harveian oration (1926) on the debt of medicine to the experimental method of Harvey, which may be read as supplementary, and as showing the other side of the shield, to the debt of science to medicine, the subject of Sir Archibald Garrod's Harveian oration of 1924 .

Though a general physician, as shown in his Lumleian lectures, Sir John was best known for his work on kidney disease; he wrote standard articles in the second edition (1908) of the "System of Medicine" (Allbutt and Rolleston) on the general pathology of the renal functions and on nephritis, and a special form of nephritis became known as "Rose Bradford's kidneys". In the same "System". he also gave the accounts of diabetes insipidus and gout, the latter being a revision of the original article by Sir William Roberts, whose niece he married in 1899. He brought out a small work "Clinical Lectures on Nephritis" (1898), but, though he had plenty of material, he never, from the number of other activities, had time or perhaps the inclination 